\title{
Computer aided discovery of benzimidazole derivatives on peptide deformylase as antimicrobial agent using hex
}

\author{
Ramaraj Sivakumara,*, Ramachanran Vasanthakumari Pradeepchandran ${ }^{b}$ \\ and Korlakunta Narasimha Jayaveerac \\ a Department of Pharmacy, Rathna Vel Subramaniam College of Pharmaceutical Sciences, Sulur, Coimbatore-641 402, Tamilnadu. India \\ b Department of Pharmacy, Narayana College of Pharmacy, Nellore-524002, Andrapradesh, India \\ c Jawaharalal Nehru Technological University of College of Engineering, Anantapur-515 002, Andrapradesh, India
}

${ }^{*}$ Corresponding author at: Department of Pharmacy, Rathna Vel Subramaniam College of Pharmaceutical Sciences, Sulur, Coimbatore-641 402, Tamilnadu. India. Tel.: +919791903606; fax: +914222687604. E-mail address: andrilan@rediffmail.com (R.S Kumar).

\section{COMMUNICATION INFORMATION}

Received: 08 September 2010

Received in revised form: 26 October 2011

Accepted: 27 October 2011

Online: 31 December 2011

\section{KEYWORDS}

Benzimidazole

Isoxazoline-5-one

Peptide deformylase

Docking study

Antimicrobial activity

Lipinski's rule

\section{Introduction}

Docking allows the scientist to virtually screen a database of compounds and predict the strongest binders based on various scoring functions. It explores ways in which two molecules, such as drugs and a receptor, fit together and dock to each other well. The molecules binding to a receptor inhibit its function and thus act as drug. The collection of drug and receptor complex was identified via docking and their relative stabilities were evaluated using molecular dynamics and their binding affinities, using free energy simulations.

The emergence of resistance to the major classes of antibacterial agents is recognized as a serious health concern and there is still need for new classes of antibacterial agents $[1,2]$. One of the new targets receiving widespread interest from researcher groups is Peptide deformylase (PDF), [3-6] which is an iron containing metalloenzyme responsible for the removal of the $N$-formyl group from the terminal methionine residue following protein synthesis in bacteria, $[7,8]$ and this enzyme is a high priority target for antibiotic design [9]. There are several kinds of compounds, which have inhibitory activity against PDF as reported $[10,11]$. The aim of the present investigation is to synthesize new active compounds and detect their antibacterial activities by introducing benzimidazole ring $[12,13]$ to serve as a hydrogen bond donor or accepter. Moreover, some benzimidazole derivatives showed potent antibacterial activities. In order to investigate the interactions between our designed compounds and the amino acid residues of the Escherichia coli PDF.Ni enzyme, a molecular docking study was performed. From this optimization of the designed compounds, only few compounds have been selected based on the high energy values and planned to synthesize and test their antibiotic activities in vitro against various gram positive and negative bacteria of the same in future.

\section{Experimental}

Hex can also calculate Protein-Ligand Docking, assuming the ligand is rigid, and it can superpose pairs of molecules using only knowledge of their 3D shapes. It uses Spherical Polar Fourier (SPF) correlations to accelerate the calculations and its one of the few docking programs, which has built in graphics to view the result. In this work, bioinformatics tools such as biological databases like PDB (Protein Data Bank) and software's like Hex, ACD ChemSketch were used. Hex is an Interactive Molecular Graphics Program for calculating and displaying feasible docking modes of pairs of protein and DNA molecules.

\subsection{Methodology}

The structure of Peptide deformylase (PDF) (Figure 1), which is an essential target for novel antibacterial drug design, was retrieved from PDB (1G2A). All water molecules and ligands were removed from the proteins for docking studies.

Using Chemsketch the structures of these drugs were sketched. The docking analysis of these compounds with 1G2A was carried by using HEX docking software.

The parameters used in HEX for the docking process were

- Correlation type - Shape only

- FFT Mode - 3D fast lite

- Grid Dimension - 0.6

- Receptor range - 180

- Ligand Range - 180 
- Twist range - 360

- Distance Range - 40

The drug and its analogues were docked with the receptor using the above parameters.

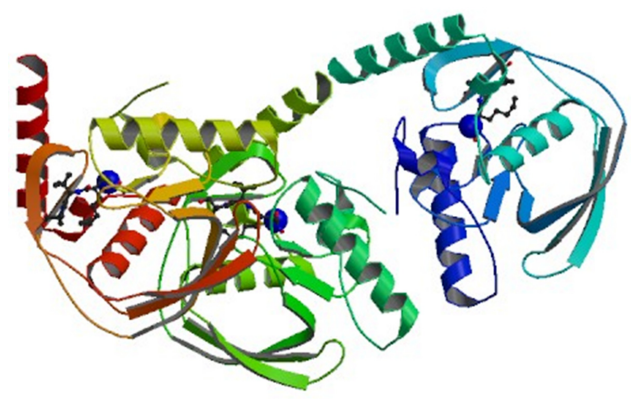

Figure 1. Structure of sterol peptide deformylase (PDF) (1G2A).

\section{Results and discussion}

Docking results between sterol peptide deformylase (PDF) 1G2A receptor and designed benzimidazole derivatives containing isoxazolin-5-one moiety (Figure 2) are reported in Table 1 .

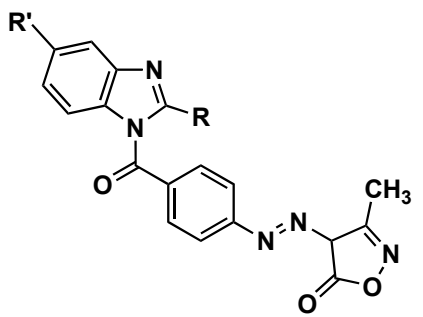

Figure 2. Basic structure of benzimidazole derivatives containing isoxazolin-5-one moiety.

Table 1. Docking results of $1 \mathrm{G} 2 \mathrm{~A}$ enzyme with benzimidazole derivatives containing isoxazolin-5-one moiety (Figure 2).

\begin{tabular}{llll}
\hline $\begin{array}{l}\text { Compound } \\
\text { docked }\end{array}$ & $\mathbf{R}$ & $\mathbf{R}^{\prime}$ & E-value \\
\hline 1 & $-\mathrm{H}$ & $-\mathrm{H}$ & -264.39 \\
2 & $-\mathrm{CH}_{3}$ & $-\mathrm{H}$ & -258.10 \\
3 & $-\mathrm{CH}_{2} \mathrm{C}_{6} \mathrm{H}_{5}$ & $-\mathrm{H}$ & -325.17 \\
4 & $-\mathrm{CH}(\mathrm{OH}) \mathrm{CH}(\mathrm{OH})-\mathrm{COOH}$ & $-\mathrm{H}$ & -294.97 \\
5 & $-\mathrm{CH}=\mathrm{CH}-\mathrm{C}_{6} \mathrm{H}_{5}$ & $-\mathrm{H}$ & -299.28 \\
6 & $-\mathrm{C}_{6} \mathrm{H}_{4}(\mathrm{o}-\mathrm{COOH})$ & $-\mathrm{H}$ & -265.44 \\
7 & $-\mathrm{C}_{6} \mathrm{H}_{4}(\mathrm{o}-\mathrm{OH})$ & $-\mathrm{H}$ & -290.47 \\
8 & $-\mathrm{CH}_{2} \mathrm{CH}_{2}-\mathrm{COOH}$ & $-\mathrm{H}$ & -289.64 \\
9 & $-\mathrm{H}$ & $-\mathrm{NO}_{2}$ & -259.22 \\
10 & $-\mathrm{CH}_{3}$ & $-\mathrm{NO}_{2}$ & -305.67 \\
11 & $-\mathrm{CH}_{2} \mathrm{C}_{6} \mathrm{H}_{5}$ & $-\mathrm{NO}_{2}$ & -272.82 \\
12 & $-\mathrm{CH}_{5}(\mathrm{OH}) \mathrm{CH}(\mathrm{OH})-\mathrm{COOH}$ & $-\mathrm{NO}_{2}$ & -217.46 \\
13 & $-\mathrm{CH}_{2} \mathrm{CH}-\mathrm{C}_{6} \mathrm{H}_{5}$ & $-\mathrm{NO}_{2}$ & -309.78 \\
14 & $-\mathrm{C}_{6} \mathrm{H}_{4}(\mathrm{o}-\mathrm{COOH})$ & $-\mathrm{NO}_{2}$ & -245.62 \\
15 & $-\mathrm{C}_{6} \mathrm{H}_{4}(\mathrm{o}-\mathrm{OH})$ & $-\mathrm{NO}_{2}$ & -265.96 \\
16 & $-\mathrm{CH}_{2} \mathrm{CH}_{2}-\mathrm{COOH}$ & $-\mathrm{NO}_{2}$ & -235.23 \\
Amoxicillin & - & - & -237.61 \\
Ciprofloxacin & - & - & -229.60 \\
\hline
\end{tabular}

Based on the literature it has been shown clearly that benzimidazole containing isoxazoline-5-one derivatives which can be a potent antibacterial agent have been used to target Peptide deformylase (PDF). The standard antibacterial agents Amoxicillin and Ciprofloxacin on docking with 1G2A produce energy values of -237.61 (Figure 3) and -229.60 (Figure 4), respectively. The energy values were calculated using Hex. Among all the designed compounds, the compound $\mathbf{3}$ containing benzyl group at $2^{\text {nd }}$ position of benzimidazole shows better binding nature, which resulted in a decrease in the energy value. Computationally designed ligands along with the compounds were pre-filtered for their drug like properties by lipinski's rule [14].

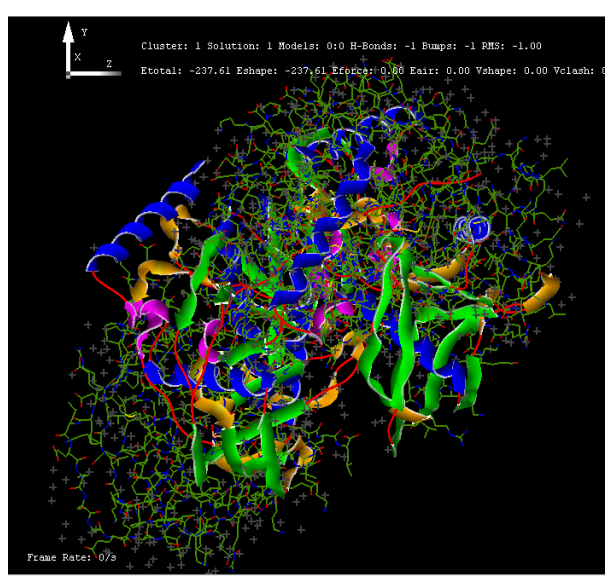

Figure 3. Interaction and binding energy of Amoxicillin with Peptide deformylase (PDF) (1G2A).

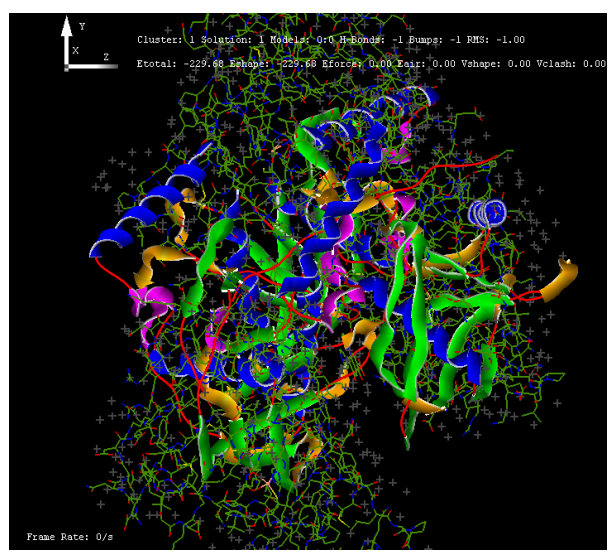

Figure 4. Interaction and binding energy of ciprofloxacin with Peptide deformylase (PDF) (1G2A).

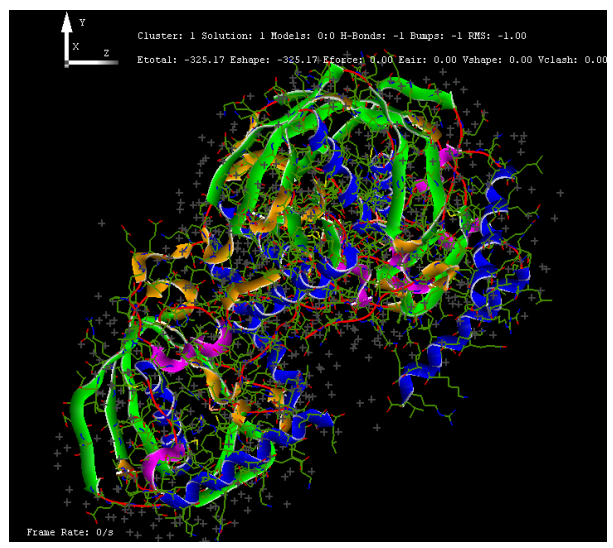

Figure 5. Interaction and binding energy of compound 3 with Peptide deformylase (PDF) (1G2A). 


\section{Conclusion}

When the Peptide deformylase (PDF) receptor (1G2A), which is an essential target for novel antibacterial drug design, was docked with amoxicillin and ciprofloxacin and the energy values obtained were -237.61 and -229.60 respectively. Applying Lipinski's rule of five to these benzimidazole derivatives to evaluate drug-likeness, there was no violation of the rule determining drugs pharmacological activity in the body. When the designed benzimidazole containing isoxazolin5-one derivatives were docked against the same receptor, the energy values are grater than the standards for some derivatives. So, it can be concluded that the designed compounds can be potent antibacterial agent. In future research, these benzimidazole derivatives will be synthesized and screen for their in-vitro anti-bacterial activity.

\section{References}

[1]. Cassell, G. H.; Mekalanos, J. J. Am. Med. Assoc. 2001, 285, 601-605.

[2]. Heinemann, J. A.; Ankenbauer, R. G.; Amabile-cuevas, C. F. Drug Discov. Today 2000, 5, 195-204.

[3]. Yuan, Z.; Trias, J.; White, R. J. Drug Discov. Today 2001, 6, 954-961.

[4]. Clements, J. M.; Ayscough, A. P.; Keavey, K.; East, S. P. Curr. Med. Chem. Anti-Infect Agents 2002, 1, 239-249.

[5]. Leeds, J. A.; Dean, C. R. Curr. Opin. Pharm. 2006, 6, 445-452.

[6]. Yuan, Z.; White, R. J. Biochem. Pharmacol. 2006, 71, 1042-1047.

[7]. Adams, J. M.; Capecchi, M. Proc. Natl. Acad. Sci. U. S. A. 1966, 55, $147-$ Adam.

[8]. Adams, J. M. J. Mol. Biol. 1968, 33, 571-574.

[9]. Berg, A. K.; Manokaran, S.; Eiler, D.; Kooren, J.; Mallik, S.; Srivastava, D. K. Protein Sci. 2008, 17, 11-15.

[10]. Giglione, C.; Pierre, M.; Meinnel, T. Mol. Microbiol. 2000, 36, 11971205.

[11]. Butler, M. S.; Buss, A. D. Biochem. Pharmacol. 2006, 71, 919-929.

[12]. Arya, P.; Rao, N. V.; Singkhonrat, J. J. Org. Chem. 2000, 65, 1881-1885.

[13]. Natchus, M. G.; Cheng, M.; Wahl, C. T.; Pikul, S.; Almsted, N. G.; Bradley, R. S.; Taiwo, Y. O.; Mieling, G. E.; Dunaway, C. M.; Snider, C. E.; Mclver, J. M.; Barnett, B. L.; Mcphail, S. J.; Anastasio, M. B.; De, B. Bioorg. Med. Chem. Lett. 1998, 8, 2077-2080.

[14]. Sivakumar, R.; Kumarnallasivan, P.; Vijai Anand, P. R.; Pradeepchandran, R.; Jayaveera, K. N.; Venkatnarayanan, R. Der Pharma Chem. 2010, 2(3), 100-108. 